\title{
Drivers of songbird productivity at a restored gravel pit: influence of seasonal flooding and rainfall patterns and implications for habitat management
}

\author{
Nancy Harrison* and Mick Whitehouse
}

Animal and Environmental Research Group, Department of Life Sciences, Anglia Ruskin University, East Road, Cambridge CB1 1PT, U.K.

*Corresponding author. Telephone: +44 01223 363271. Fax: +44 01223417712.

E-mail address: Nancy.harrison@anglia.ac.uk

\begin{abstract}
The restoration of riparian sites following aggregate extraction frequently aims to expand the wetland habitat, and enhance the wetland wildlife community. However, aggregate extraction sites, typically on river flood plains, are subject to unpredictable flooding along with climate variability and other factors beyond the control of local management that may be equally important in determining the success or failure of a restoration project. Here we report on an 18 year study tracking songbird productivity and changes in the avian community following the restoration of a gravel pit on the flood plain of the River Great Ouse, Cambridgeshire. As part of the British Trust for
\end{abstract}


Ornithology’s Constant Effort Site ringing scheme, the productivity (ratio of young: adult captured) of 5 migrant and 6 resident species was measured systematically. Capture data along with environmental variables pertinent to the flood plain habitat were analysed using Generalised Linear Models. For some migrant species (e.g. willow warbler Phylloscopus trochilus and reed warbler Acrocephalus scirpaceus) breeding success was predicted by maximum winter flood. The productivity of resident species (e.g. dunnock Prunella modularis) was predicted not only by the overall amount of rain (positively related to production) but also the extent of spring downpours (negatively related to production). We expected that a major influence on the avian community would be the passage of time and associated vegetation succession. However, winter flood was found to be particularly important, as to a lesser extent was spring rain and unseasonal cold snaps. Detrended Correspondence Analysis of the total numbers of birds captured (adults + young) for 16 species showed that the changing avian community was shaped by winter floods more than by patterns in precipitation. It would appear that the avian community is influenced by patterns of habitat change, shaped as much by climate variability as local land management.

Keywords: passerine productivity; East Anglia; gravel pit; climate change; flood; rainfall; temperature; bird ringing 


\section{Introduction}

The avian community of East Anglia in eastern England occupies a patchwork of habitat profoundly altered historically with the drainage of fens and control of waterways and subsequently as the result of intensive agriculture and urbanisation (NERC et al. 2009, Maltby et al. 2011). The remnants of wetlands and riparian habitats are critically important for a diversity of birds. The undeveloped habitat along flood plains is important for species other than riparian and wetland specialists as well. In a landscape shaped increasingly by agriculture and urbanisation, riparian habitat offers a secure breeding location for species that feed in the surrounding habitat mosaic (Whited et al. 2000). Also these habitat corridors are important in landscape-scale processes of dispersal, helping secure regional populations (Morris 1992).

Two further aspects in the continued change of these dynamic riparian environments are the industrial extraction of aggregates from them and the increasingly unpredictable patterns of rainfall and flooding as a consequence of climate change (Murphy et al. 2009, UK Met Office 2011). Following aggregate extraction, habitat management in wetlands and riparian corridors over the past 20 years has resulted in an expansion of wildlife habitat in eastern England. This redevelopment of extensive floodplains for nature conservation represents a major benefit for wildlife as even small-scale habitat recreation can be disproportionately important for the region's birdlife. However, given the growing population of East Anglia and its importance for agriculture, increasing human demands are likely to have priority over nature 
conservation on water resources making wetland and riparian habitats particularly vulnerable (Schleupner 2010, Hughes et al. 2011, Mori 2011). Meta-analyses have shown that climate change is already having an impact on the distribution and abundance of species (e.g. Parmesan and Yohe 2003) but the effects of habitat degradation are also important factors influencing bird populations in the heavily populated landscape of East Anglia (e.g. Eglington and Pearce-Higgins 2012). While local habitat loss and degradation has shaped the landscape in this region, wetland and riparian habitats are likely to be among those most affected by climate change (Maltby et al. 2011).

Here we report on a long term investigation of the birdlife at a restored gravel pit on a flood plain that has been subject to substantial variability in water availability. Data were collected as part of the British Trust for Ornithology’s (BTO) Constant Effort Site (CES) ringing scheme; the focus of this ringing scheme is the evaluation of productivity in breeding passerines, and it has provided insights into the drivers of population change (Peach et al. 1996). For instance, analyses of willow warbler Phylloscopus trochilus productivity data found evidence that regional-scale drivers explain differences in population change between northern and southern England (Morrison et al. 2010). With the influence of climate change on rainfall and flooding, it is a reasonable hypothesis that one such regional driver of population change may be the impact of changing climatic conditions on the rivers of East Anglia (Wilby 2006, UK Met Office 2011). We used 18 years of CES data to explore the importance of rainfall, seasonal flooding and temperature on the variability of passerine productivity, and changes to the avian community. Habitat specialists such as the Acrocephalus warblers (reed bed specialists) would be predicted to be sensitive to 
seasonal floods that influence the ecology of the site. But other species may also be sensitive to flooding and rainfall that would influence the site's overall 'greenness' (Albright et al. 2010), and ultimately the extent and quality of the foraging habitat. Drought conditions would be expected to result in lower productivity across most species, and would favour generalist species over wetland specialists. But rainfall is unlikely to have a simple influence on productivity. While increased rainfall is associated with 'greenness' and would be expected to have a positive influence on productivity, ill-timed downpours are likely to have a negative effect on breeding birds because of the difficulties faced by leaf-gleaning species in finding invertebrate prey.

We considered the impact of rainfall on the productivity of resident and migrant birds in two respects: (1) the affect of overall rainfall and (2) the affect of downpours. Further, we considered the influence of cold snaps in spring and summer and whether this is changing through time. These questions are pertinent given the projected changes in climate, the increasingly unpredictable patterns of rainfall, the occurrence of storms, and the increased demands on water resources, all affecting patterns in flooding (Schär et al. 2004, Schleupner 2010, Vörösmarty et al. 2010, UK Met Office 2011).

\section{Methods}

\subsection{Study area and data sources}


The study area ( 12 ha, grid reference TL259723) is on the flood plain of the River Great Ouse and is part of the Cow Lane Nature Reserve (see Harrison et al. 2000). It is a former willow coppice (mix of species, mostly Salix viminalis), and aggregates were extracted from the centre of the willow coppice from 1984-1986. This study was carried out for 18 years from 1989 to 2006 as part of the BTO’s CES ringing scheme that monitors passerine productivity. Birds were captured in mist nets (120 m total length) deployed at standard sites from dawn to midday once every 10 days between May and August (Peach et al. 1996).

Total catch data (adults + juv) for 16 passerine species that breed on the site were used in the data analysis (Table 1). Productivity (juvenile/adult catch) was analysed in eleven of the species, 5 migrants (willow warbler, chiffchaff Phylloscopus collybita, blackcap Sylvia atricapilla, reed warbler Acrocephalus scirpaceus, sedge warbler Acrocephalus schoenobaenus) and 6 residents (wren Troglodytes troglodytes, dunnock Prunella modularis, blackbird Turdus merula, blue tit Cyanistes caeruleus, great tit Parus major, long-tailed tit Aegithalos caudatus). Proportion of juveniles to adults across summer months from systematic ringing schemes has been established as representative of true productivity (Dunn and Ralph 2004, Peach et al. 1996).

The environmental data included: (1) annual maximum winter flood (mean daily gauged flow [million $\mathrm{m}^{3} \mathrm{~s}^{-1}$ ] for the winter month with the highest flood waters); (2) daily rainfall; (3) daily temperature. Data on river levels were from the Environment Agency’s nearest gauge on the river Great Ouse at Bedford (grid reference TL055495). Daily rainfall and temperature data were from the Cambridge University Botanic Garden (grid reference TL455571); while $25 \mathrm{~km}$ from the study site, this data 
source was the nearest to provide detail in patterns of temperature and rainfall needed for analyses.

Variables used in analyses comprised: (1) year, from 1989 - 2006; (2) year band, 3yearly intervals - 1989-1991, 1992-1994, 1995-1997, 1998-2000, 2001-2003 and 2004-2006. The variable 'year band' was used to explore long term trends; we dampened year-to-year variability by dividing the 18 study years into 6 bands at 3yearly intervals. Environmental variables used in analyses included: (3) winter flood; (4) total annual rainfall; (5) monthly rainfall (April - August); (6) 'summer downpours', number of days with >5 mm rainfall for each month (April - August); (7) temperature. An index of spring and summer cold snaps (a sudden short spell of cold weather) was established by first calculating a day of the year mean and standard deviation (SD) from daily minimum temperatures between May and August for the years 1989 to 2006 inclusive. A 7 day running average through this mean minus the SD was our threshold of typical temperature variation and deviations below this were identified as cold snaps. The resulting index representing a cold snap was the number of days below this threshold multiplied by temperature difference from the running average.

\subsection{Statistical analyses}

\subsubsection{Generalised linear models}

We used generalised linear models (GLM) to explore the statistical relationships between productivity in 11 breeding species and environmental variables. 
Productivity was taken to be the ratio of young to adult birds captured during 18 years of systematic ringing at our CES site, and the model assumed a binomial distribution with a logit link. Where distributions were over-dispersed, a quasi-binomial distribution was used. The best models were selected through reverse deletion; competing models were evaluated using the Akaiki information criterion (AIC), or when using quasi-binomial distributions, models were evaluated using $p$ values. All analyses were carried out using R, version 2.8.1 (R Development Core Team 2008).

\subsubsection{Detrended correspondence analysis}

Detrended correspondence analysis (DCA) was used on the CES ringing dataset to examine the relative abundance of 16 species through the 18 years of the study. The total numbers of birds captured (adult and juvenile) were log transformed, and DCA carried out using PC Ord Software (McCune and Mefford 1999). The explained variance was estimated using Relative Euclidean as a distance measure, in order to estimate the relative importance in variation related to year band (3-yearly intervals), changes in flooding and climate through time, and annual fluctuations in rainfall and temperature.

\section{Results}

\subsection{Passerine productivity}

Productivity was characterised by high variation (Table 1), and species differed in the extent to which their productivity appeared to be explained by winter floods, or spring 
and summer weather (Table 2). Analyses for the most common breeding species on the site indicated that the maximum winter flood level was a significant factor, positively related to productivity for three of the four migrant warbler species as it was in an interaction with year for sedge warbler. Only rarely did productivity closely track local environmental variables, for example productivity in willow warbler tracked varying winter floods (Fig. 1; Spearman's rank correlation rho $=389.5, p$ $<0.01$ ). For resident species, productivity was related to winter flood for only the blackbird. Productivity for this ground-feeding species (the only one in the analysis) was positively related to winter flooding and also to summer downpours (Table 2).

Productivity in most of the resident species, and the chiffchaff, appears to be more related to rainfall (Table 2). However, the relationships between the variables were complex. For example, dunnock productivity was positively related to rainfall but negatively related to summer downpours. In contrast, chiffchaff productivity was negatively associated with rainfall, but positively associated with downpours. These differences are likely to relate to how the birds are responding to rainfall (or to the consequences in terms of habitat and insect availability) in generally wet or dry years.

Models were also constructed for blackcap, wren, and great tit. For these species there was a large sample size and yet no significant patterns with rainfall, downpours, flooding, cold snaps, or the passage of time over the 18 years of the study.

\subsection{Changing avian community and associated variables}


We explored patterns though the 18 years of study in the total numbers of the passerines caught during CES ringing using DCA. DCA permitted us to relate multiple response and explanatory variables, and the resulting species-environmental variable biplot (Fig. 2) suggests flooding may be important in explaining changes in the avian community. Axis 1 explained the most variation (41\%) in the data for total numbers of birds; the progression from right to left reflects time elapsed (the variable year band) from the first years of the project to the last years (as indicated by the arrow labelled time), however, winter flooding was also important in shaping the pattern (Fig. 3). The biggest shifts in relative abundance of species were reflected in axis 1 , song thrush and sedge warbler, once common on the site but now less so, to the extreme right. Axis 2 accounted for $13 \%$ of variation and was associated with the index of cold snaps, and also winter flooding (Fig. 3). Migrant warblers occurred across the bottom of the graph, separated from resident species on axis 2 (Fig. 3). Our index for cold snaps was significantly correlated with year (Fig. 4; Spearman’s rank correlation rho $=1277.8, p<0.05$ ), after excluding an outlier by the method proposed by Dixon (Sokal and Rolf 1995). The outlier was 1996 which represented an extreme, with nearly three times the number of unseasonal cold days than any other year.

\section{Discussion}

Winter flooding and rainfall, have been shown in this research to have marked effects on the breeding success of passerines, and be influential in shaping the avian community. These results show a number of parallel patterns between species' productivity and suggest that the changes are a real response to habitat change (Dunn et al. 2004) which is concomitant with climate change (Davey et al. 2012) and permit 
predictions of how avian productivity will be affected as a consequence of future climate change. The species studied here are (with the exception of bullfinch) insectivorous passerines, and for these species the influence of flooding and rainfall on habitat ('greenness') and prey availability are important determinants of species richness and abundance. Rainfall has been associated with high passerine productivity however downpours can result in young perishing in the nests (Skagen and Yackel Adams 2012). Angelier et al. (2011) found a positive relationship between rainfall and body condition in a Neotropical migrant warbler, but the positive effect of rain was no longer evident if birds were exposed to downpours. Prey abundance and its availability to a foraging bird are likely to be interacting in our analyses, with more prey during a wet spring, but problems with finding and catching it in a cold snap or during a downpour.

Understanding how environmental variation influences productivity involves untangling multiple confounding factors. The CES ringing programme of the BTO has shown that many patterns in productivity are regional, with higher percentages of juveniles captured on wet sites (Peach et al. 1996). Less is known about what characteristics of wet sites are important, but more focused studies such as the current one should help direct attention to the key variables (Peach et al. 1998). The BTO data have shown that willow warblers and chiffchaffs are both sensitive to changes in wet habitat, but do not have high productivity in the same years (Peach et al. 1996). Our analysis suggests that the productivity of both Phylloscopus species is highest in wet years, but while willow warblers were sensitive to flood conditions, chiffchaffs were sensitive to rainfall. Such inter-specific variation is important in understanding 
how species differ in their response to environmental change, and their relative vulnerability to the changing climate (Salido et al. 2012).

Our finding that winter flooding had a significant influence on productivity for a number of migrant warblers, including the specialist wetland species, is noteworthy. For reed warblers and sedge warblers changes in winter flooding are likely to be important in shaping the quality of reed beds and other wetland vegetation in spring. However, the strong pattern we documented in willow warblers may be a combination of the effects on habitat and the elimination of predators from the flood plain in years of extreme flood. Following dry winters we found very high rates of predation by weasels Mustela nivalis in nest boxes (pers. obs.). Weasels are known to be important predators on nestling birds and surprisingly are among the most important predators of nestlings in nest boxes, small female weasels readily passing through even small entry holes (Perrins 1979). We hypothesise that riparian zones may vary in quality as habitat for breeding migrant warblers for multiple reasons, not only the expanse of wetland habitat but the influence of winter flood levels in controlling ground predators.

The 18 years of data from Cow Lane show productivity in migrant and resident species to be sensitive to different environmental variables (rainfall, flood levels and temperature), and changes are emerging in productivity that appear to be leading to a shifting balance in the community. We expected the passage of time to have associated changes, with lower relative abundance of species such as sedge warbler and willow warbler (Peach et al. 1991, Peach et al. 1995), but the high proportion of variation explained by winter flooding was not expected. The subtle shift in the 
community at Cow Lane appears to be favouring generalist resident species. Davey et al. (2012) examined BTO data for Britain over the same years as our study and found evidence of community level changes, with a trend toward more generalists and fewer specialist species. Generalists, with greater flexibility in life history (timing of breeding), in habitat use and in diet will be at an advantage when challenged with environmental perturbations (Salido et al. 2012).

This long-term study at the Cow Lane Nature Reserve has provided indications of the drivers of passerine productivity - winter flooding and patterns in precipitation. The original vision of habitat creation after aggregate extraction followed a common model, in which very specific goals were set for a wetland community. However, these goals may have been unrealistic and may be increasingly so given the important factors outside the control of managers (Hilderbrand et al. 2005, Hughes et al. 2012). Site specific goals will be difficult to achieve on intensively managed flood plains, with a large growing human population and increased demands on land use and water resources (Hughes et al. 2001, Vörösmarty et al. 2010).

The successful management of habitats such as that at Cow Lane Nature Reserve will require a landscape scale rather than local to fulfil the potential of the many small riparian sites along the region's rivers, and maintain their importance within the matrix of semi-natural, agricultural and urban habitats (Whited et al. 2000). Recreated wetland represents an increasingly important habitat in East Anglia in terms of nature conservation, despite the region being the driest in the UK; the average annual rainfall of $600 \mathrm{~mm}$ is $70 \%$ of the national average (Environment Agency 2009). There are ambitious goals for substantial expanses of semi-natural habitat as part of the Wetland 
Vision: Great Fen Project, Wicken Fen Vision, Waveney/Little Ouse TEN project, Wet Fens for the Future Project (Hughes et al. 2005, Environment Agency 2009, Warrington et al. 2009). In addition to these large designated nature reserves, small, interlinking riparian habitat fragments may be crucial in supporting breeding passerine populations (Passinelli et al. 2008) but are not typically part of river basin management. Projections to 2050 indicate a far greater overall water demand and substantially reduced availability for the environment (Environment Agency 2009), and sustainable management of water resources will be most effective if there is a good understanding of the importance of flooding in shaping riparian ecosystems.

\section{Conclusion}

The primary drivers of passerine productivity were found to be winter flood levels and patterns of rainfall, with migrant warblers having their best years following big winter floods, and resident species sensitive to rainfall. Climate change potentially threatens the viability of certain breeding birds, through changes in river levels, precipitation and temperature, and the frequency of spring storms. Migrant and resident species may be affected in different ways with the potential for changing the balance in avian communities. These trends, which are likely to become more pronounced with ongoing climate change, make it difficult to anticipate the trajectory of habitat change following habitat restoration. East Anglia's patchwork of habitats will inevitably include many small habitat fragments, including those that result from gravel pit restoration. Our results highlight the importance of river basin management, specifically the importance of winter flooding for biodiversity conservation. 
Acknowledgements

We thank the landowners (Redland and Lafarge Aggregates) for allowing us access to their land and the kind assistance of their staff. We are grateful to the Environment Agency and the Cambridge University Botanic Garden for supplying data to us. We are also grateful to two anonymous referees whose comments have helped us improve the paper. Finally we thank the late Peter Prince our mentor and friend and tireless worker at Cow Lane.

\section{References}

Albright, T.P., Pidgeon, A.M., Rittenhouse, C.D., Clayton, M.K., Flather, C.H., Culbert, P.D., Wardlow, B.D., Radeloff, V.C., 2010. Effects of drought on avian community structure. Glob. Change Biol. 16, 2158-2170.

Angelier, F., Tonra, C.M., Holberton, R.L., Marra, P.P., 2011. Short-term changes in body condition in relation to habitat and rainfall abundance in American redstarts Setophaga ruticilla during the non-breeding season. J. Avian Biol. 42, 335-341. Davey, C.M., Chamberlain, D.E., Newson, S.E., Noble, D.G., Johnston, A., 2012. Rise of the generalists: evidence for climate driven homogenization in avian communities. Global ecol. and Biogeogr. 21, 568-578.

Dunn, E.H., Ralph, C.J., 2004. Use of mist nets as a tool for bird population monitoring. Stud. Avian Biol. 29, 1-6. 
Dunn, E.H., Hussell, D.J.T., Adams, R.J., 2004. An investigation of productivity indices derived from banding of fall migrants. Stud. Avian Biol. 29, 92-96.

Environment Agency, 2009. Water for People and the Environment. Water Resources Strategy. Regional Action Plan for the Anglian Region.

Eglington, S.M., Pearce-Higgins, J.W., 2012. Disentangling the relative importance of changes in climate and land-use intensity in driving recent bird population trends. PLoS ONE 7(3): e30407. doi:10.1371/journal.pone.0030407.

Harrison, N.M, Whitehouse, M.J., Prince, P.A., Huin, N., 2000. What problems do local habitat change represent for the Constant Effort Site ringing scheme. Ringing and Migration 20, 1-8.

Hilderbrand, R., Watts, A.C., Randle, A.M., 2005. The myths of restoration ecology. Ecol. and Soc. 10, 19. [online] URL:

http://www.ecologyandsociety.org/vol10/iss1/art19

Hughes, F.M.R., Colston, A., Mountford, J.O., 2005. Restoring riparian ecosystems: the challenge of accommodating variability and designing restoration trajectories. Ecol. and Soc. 10, 12 (online) URL http://www.ecologyand society.org/vol10/iss1/art12/ (accessed 15 Feb 2012)

Hughes, F.M.R., Adams, W.M., Stroh, P.A., 2012. When is open-endedness desirable in restoration projects? Restor. Ecol. 20, 291-295.

Hughes, F.M.R., Adams, W.M., Muller, E., Nilsson, C., Richards, K.S., Barsoum, N., Decamps, H., Foussadier, R., Girel, J., Guilloy, H., Hayes, A., Jouansson, M., Lambs, L., Pautou, G., Piry, J.-L., Perrow, M., Vautier, F., Winfield, M., 2001. The importance of different scale processes for the restoration of floodplain woodlands. Regul. River 17, 325-345. 
Hughes, F.M.R., Stroh, P.A., Adams, W.A., Kirby, K., Mountford, J.O., Warrington, S., 2011. Monitoring and evaluating landscape-scale, open-ended habitat creation projects: a journey rather than a destination, J. Nature Cons.19, 245-253.

Jiguet, F., Brotons, L., Devictor, V., 2011. Community responses to extreme climatic conditions. Current Zoology 57, 406-413.

Maltby, E., Ormerod, S., Acreman, M., Dunbar, M., Jenkins, A., Maberly, S.

Newman, J., Blackwell, M., Ward, R., 2011. Freshwaters: openwaters, wetlands and floodplains (chapter 9) In: UK National Ecosystem Assessment: understanding nature’s value to society. Technical Report. Cambridge, UK, UNEP-WCMC, 295360.

McCune, B., Mefford, M.J., 1999. PC-ORD for Windows: multivariate analysis of ecological data. MjM Software, Gleneden Beach, Oregon, USA.

Mori, A.S., 2011. Ecosystem management based on natural disturbances: hierarchical context and non-equilibrium paradigm. J. app. Ecol. 48, 280-292.

Morris, D.W., 1992. Scales and costs of habitat selection in heterogeneous landscapes. Evol. Ecol. 6, 412-432.

Morrison, C.A., Robinson, R.A., Clark, J.A., Gill, J.A., 2010. Spatial and temporal variation in population trends in a long-distance migratory bird. Divers. Distrib. 16, 620-627.

Murphy, J.M., Sexton, D.M.H., Jenkins, G.J., Boorman, P.M., Booth, B.B.B., Brown, C.C., Clark, R.T., Collins, M., Harris, G.R., Kendon, E.J., Betts, R.A., Brown, S.J., Howard, T.P., Humphrey, K.A., McCarthy, M.P., McDonald, R.E., Stephens, A., Wallace, C., Warren, R., Wilby, R.L., Wood, R.A., 2009. UK Climate Projections Science Report: Climate change projections. Met Office Hadley Centre, Exeter. 
NERC/Centre for Ecology and Hydrology, Defra, Natural England. 2009.

Countryside Survey: England Results from 2007. NERC/Centre for Ecology and Hydrology, 119 pp.

Passinelli, G., Mayer,C., Gouskov, A., Schiegg, K., 2008. Small and large wetland fragments are equally suited breeding sites for a ground-nesting passerine. Oecologia 156, 703-714.

Parmesan, C., Yohe, G., 2003. A globally coherent fingerprint of climate change impacts across natural systems. Nature 421, 37-42.

Peach, W., Bailie, S., Underhill, L., 1991. Survival of British sedge warblers Acrocephalus schoenobaenus in relation to west African rainfall. Ibis 133, 300-305. Peach, W.J., Baillie, S.R., Balmer, D.E., 1998. Long-term changes in abundance of passerines in Britain and Ireland as measured by constant effort mist-netting. Bird Study 45, 257-275.

Peach, W.J., Buckland, S.T., Baillie, S.R., 1996. The use of constant effort mistnetting to measure between-year changes in the abundance and productivity of common passerines. Bird Study 43, 142-156.

Peach, W.J., Crick, H.W.P., Marchant, J.H., 1995. The demography of the decline in the British willow warbler population. J. App. Stat. 22, 905-922.

Perrins, C., 1979. British Tits. Collins, London.

R Development Core Team, 2008. R, a language and environment for statistical computing. R Foundation for Statistical Computing. R Foundation for Statistical Computing, Vienna, Austria. [online] URL: http://www.R-project.org.

Salido, L., Purse, B.V., Marrs, R., Chamberlain, D.E., Shultz, S., 2012. Flexibility in phenology and habitat use act as buffers to long-term population declines in UK passerines. Ecography 35, 604-613. 
Schär, C., Vidale, P.L., Luthi, D., Frei, C., Haberli, C., Liniger, M.A., Appenzeller,

C., 2004. The role of increasing temperature variability in European summer heatwaves. Nature 427, 332-336.

Schleupner, C., 2010. Modeling the implications of climate change for European freshwater wetland distributions - a review of knowledge and gaps. Journal of climate change - impacts and responses 2(3), 37-62.

Skagen, S.K., Yackel Adams, A.A., 2012. Weather effects on avian breeding performance and implications of climate change. Ecol. Appl. 22(4), 1131-1145.

Sokal, R.R., Rohlf, F.J., 1995. Biometry. W.H. Freeman and Co., New York.

Taylor, L.R., 1991. Proper studies and the art of the soluble. Ibis 133 suppl. I, 9-23.

UK Met Office, 2011. Climate: observations, projections and impacts. December 2011. http://www.metoffice.gov.uk/media/pdf/t/r/UK.pdf

Warrington, S., Soans, C., Cooper, H., 2009. The Wicken Vision: the first 10 years. Ecos 30, 58-65.

Vörösmarty, C.J., McIntyre, P.B., Gessner, M.O., Dudgeon, D., Prusevich, A., Green, P., Glidden, S., Bunn, S.E., Sullivan, C.A., Reidy Liermann, C., Davies, P.M., 2010.

Global threats to human water security and river biodiversity. Nature 467, 555-561.

Whited, D., Galatowitsch, S., Tester, J.R., Schik, K., Lehtinen, R., Husveth, J., 2000.

The importance of local and regional factors in predicting effective conservation planning strategies for wetland bird communities in agricultural and urban landscapes. Landscape Urban Plan. 49, 49-65.

Wilby, R.L., 2006. When and where might climate change be detectable in UK river flows? Geophys. Res. Lett. 33, L19407, doi:10.1029/2006GL027552. 
Table 1. Mean (SD) capture rates for adults and juveniles of 16 species in Osier Pit standard nets from 1989-2006.

\begin{tabular}{|ll|l|r|r|}
\hline Species & & Code & \multicolumn{1}{l|}{ Adult } & \multicolumn{1}{l|}{ Juvenile } \\
\hline Blackbird & Turdus merula & BLABI & $21.7(10.9)$ & $10.8(8.6)$ \\
\hline Blackcap & Sylvia atricapilla & BLACA & $18.4(7.4)$ & $29.6(15.6)$ \\
\hline Blue tit & Cyanistes caeruleus & BLUTI & $12.5(5.0)$ & $49.7(32.4)$ \\
\hline Bullfinch & Pyrrhula pyrrhula & BULLF & $5.7(3.1)$ & $6.6(4.0)$ \\
\hline Chiffchaff & Phylloscopus collybita & CHIFF & $6.1(3.7)$ & $11.5(7.5)$ \\
\hline Dunnock & Prunella modularis & DUNNO & $5.0(2.6)$ & $7.2(3.8)$ \\
\hline Garden warbler & Sylvia borin & GARWA & $7.4(4.0)$ & $7.3(4.7)$ \\
\hline Great tit & Parus major & GRETI & $10.0(5.1)$ & $25.1(13.7)$ \\
\hline Long-tailed tit & Aegithalos caudatus & LOTTI & $11.4(5.6)$ & $31.7(16.9)$ \\
\hline Reed warbler & Acrocephalus scirpaceus & REEWA & $30.7(14.8)$ & $25.9(18.8)$ \\
\hline Robin & Erithacus rubecula & ROBIN & $3.3(2.8)$ & $9.6(4.2)$ \\
\hline Sedge warbler & Acrocephalus schoenobaenus & SEDWA & $17.0(9.9)$ & $15.9(13.4)$ \\
\hline Song thrush & Turdus philomelos & SONTH & $3.1(3.6)$ & $4.8(4.1)$ \\
\hline Treecreeper & Certhia familiaris & TREEC & $0.5(0.7)$ & $4.0(2.6)$ \\
\hline Willow warbler & Phylloscopus trochilus & WILWA & $9.1(5.2)$ & $14.1(13.1)$ \\
\hline Wren & Troglodytes troglodytes & WREN & $9.5(2.8)$ & $26.7(7.3)$ \\
\hline
\end{tabular}


Table 2. Estimates of the coefficients of the best model (GLM) obtained to predict productivity for selected migrant and resident breeding species.

\begin{tabular}{|c|c|c|c|c|}
\hline & Estimate & se & $\mathrm{Z} / \mathrm{t} *$ & $\mathrm{P}$ \\
\hline \multicolumn{5}{|l|}{ Migrant species } \\
\hline \multicolumn{5}{|l|}{ Willow warbler } \\
\hline WinterFlood & 0.0425 & 0.0085 & 4.997 & $<0.001$ \\
\hline Year & -0.0759 & 0.0238 & -3.185 & $<0.001$ \\
\hline RainMay & 0.0112 & 0.0047 & 2.375 & 0.018 \\
\hline RainJune & 0.0070 & 0.0037 & 1.896 & 0.058 \\
\hline Intercept & -1.106 & 0.4814 & -2.298 & 0.023 \\
\hline \multicolumn{5}{|l|}{ Chiffchaff } \\
\hline Year & -0.1157 & 0.0401 & \begin{tabular}{|l|}
-2.887 \\
\end{tabular} & 0.003 \\
\hline RainApril & -0.0094 & 0.0046 & -2.059 & 0.039 \\
\hline RainJune & -0.0376 & 0.0157 & -2.392 & 0.017 \\
\hline June - days heavy rain & 0.4600 & 0.1838 & 2.502 & 0.012 \\
\hline Cold snaps & -0.0376 & 0.0157 & -2.392 & 0.017 \\
\hline Intercept & 3.0322 & 0.7740 & 3.917 & $<0.001$ \\
\hline \multicolumn{5}{|l|}{ Reed Warbler $\dagger$} \\
\hline WinterFlood & 0.0542 & 0.0209 & 2.601 & 0.021 \\
\hline Year & 0.0885 & 0.0591 & 1.497 & 0.157 \\
\hline WinterFlood*Year & -0.0045 & 0.0019 & -2.366 & 0.033 \\
\hline Intercept & -1.4185 & 0.6551 & -2.165 & 0.048 \\
\hline \multicolumn{5}{|l|}{ Sedge Warbler† } \\
\hline WinterFlood & 0.0341 & 0.0176 & 1.938 & 0.073 \\
\hline Year & 0.0595 & 0.0524 & 1.134 & 0.276 \\
\hline WinterFlood*Year & -0.0061 & 0.0018 & -3.353 & 0.005 \\
\hline Intercept & -0.4370 & 0.5103 & \begin{tabular}{|l}
-0.856 \\
\end{tabular} & 0.406 \\
\hline \multicolumn{5}{|l|}{ Resident species } \\
\hline \multicolumn{5}{|l|}{ Dunnock } \\
\hline RainApril & 0.0217 & 0.0097 & 2.243 & 0.025 \\
\hline April - days heavy rain & -0.3021 & 0.1538 & -1.964 & 0.049 \\
\hline RainMay & 0.0190 & 0.0095 & 2.003 & 0.045 \\
\hline RainJune & 0.0346 & 0.0214 & 1.619 & 0.105 \\
\hline June - days heavy rain & -0.2538 & 0.2374 & \begin{tabular}{|l|}
-1.069 \\
\end{tabular} & 0.285 \\
\hline Cold snaps & 0.0348 & 0.0194 & 1.796 & 0.072 \\
\hline Intercept & -2.2299 & 0.9577 & -2.328 & 0.020 \\
\hline \multicolumn{5}{|l|}{ Blackbird $\dagger$} \\
\hline WinterFlood & 0.0264 & 0.0072 & 3.662 & 0.006 \\
\hline May - days heavy rain & 0.2532 & 0.0640 & 3.958 & 0.003 \\
\hline June - days heavy rain & 0.2193 & 0.0391 & 5.615 & $<0.001$ \\
\hline July- days heavy rain & -0.2417 & 0.0730 & -3.313 & 0.010 \\
\hline Intercept & -2.3087 & 0.3790 & -6.092 & $<0.001$ \\
\hline
\end{tabular}




\begin{tabular}{|l|l|l|l|l|}
\hline & & & & \\
\hline Long-tailed tit & & & & \\
\hline Total Rain & 0.0040 & 0.0012 & 3.226 & $\mathbf{0 . 0 0 2}$ \\
\hline Year & 0.0623 & 0.03601 & 1.725 & 0.084 \\
\hline RainMay & 0.0176 & 0.0067 & 2.614 & $\mathbf{0 . 0 0 9}$ \\
\hline RainJune & 0.0618 & 0.0203 & 3.037 & $\mathbf{0 . 0 0 2}$ \\
\hline June- days heavy rain & -0.5964 & 0.2246 & -2.655 & $\mathbf{0 . 0 0 8}$ \\
\hline July- days heavy rain & -0.1225 & 0.0628 & -1.951 & 0.051 \\
\hline Cold snaps & 0.0318 & 0.0129 & 2.464 & $\mathbf{0 . 0 1 4}$ \\
\hline Intercept & -4.3772 & 1.5567 & -2.812 & $\mathbf{0 . 0 0 5}$ \\
\hline & & & & \\
\hline Blue tit $†$ & & & & \\
\hline Year & -0.0880 & 0.0333 & -2.641 & $\mathbf{0 . 0 1 9}$ \\
\hline Total Rain & 0.0044 & 0.0014 & 3.183 & $\mathbf{0 . 0 0 6}$ \\
\hline Intercept & -0.9026 & 0.9576 & -0.942 & 0.361 \\
\hline
\end{tabular}

$\dagger$ Distribution over-dispersed hence used quasi-binomial distribution

* t-value when analysis uses quasi-binomial

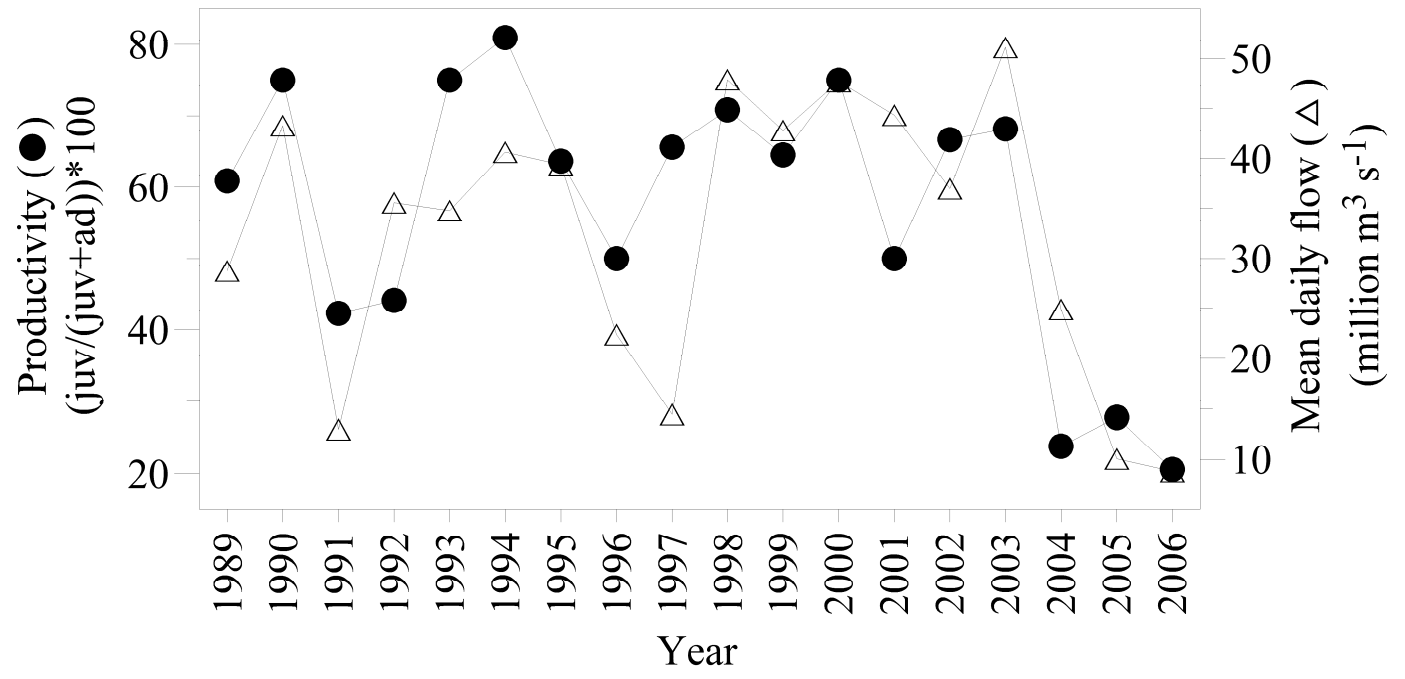

Figure 1. Variation in willow warbler Phylloscopus trochilus productivity compared with maximum winter flood (mean daily gauged flow for the winter month with the highest flood waters). 


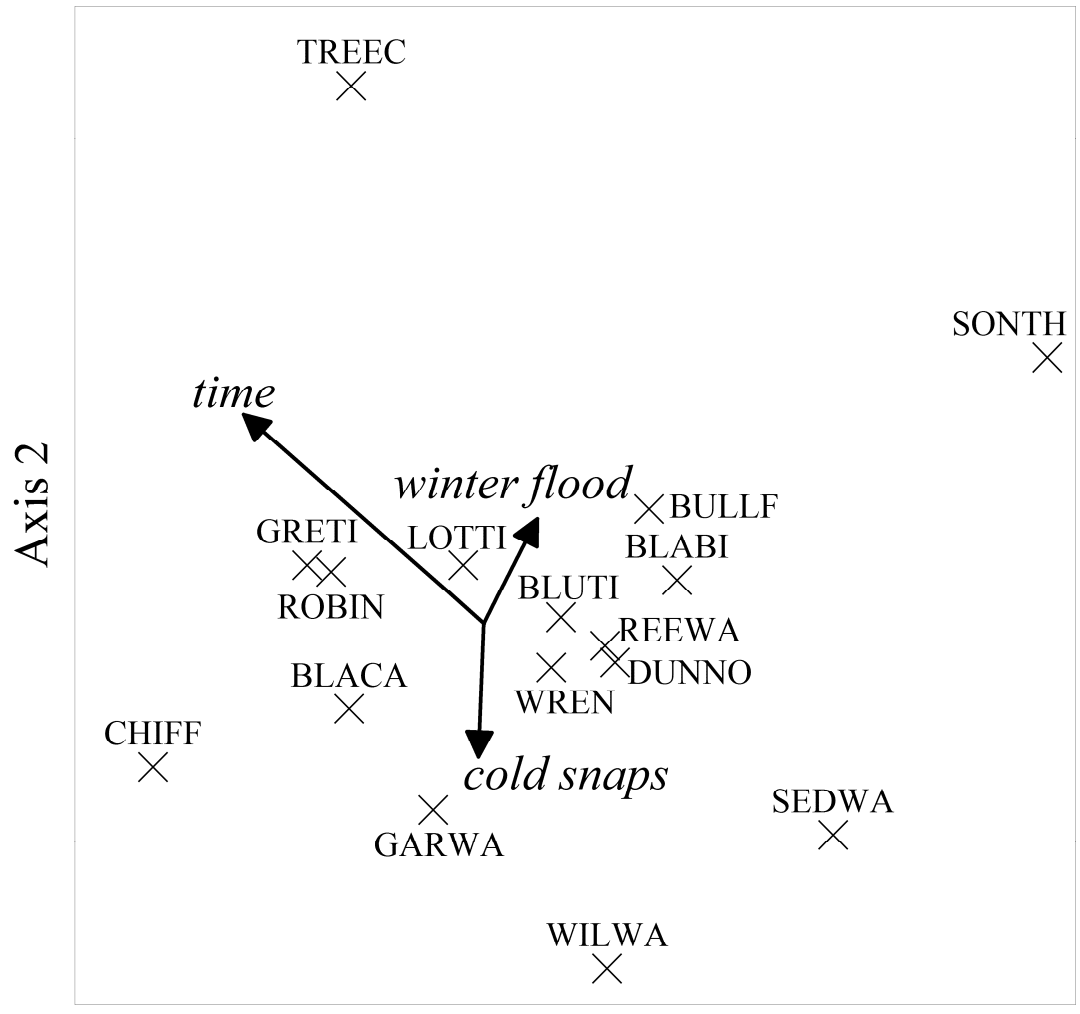

Axis 1

Figure 2. Species-environment variable biplot from a detrended correspondence analysis of species across 18 years of study. Points represent species; species codes are summarised in Table 1. Arrows represent the direction and strength of environmental variables. Time represents the variable 'year band' (3 year intervals). 

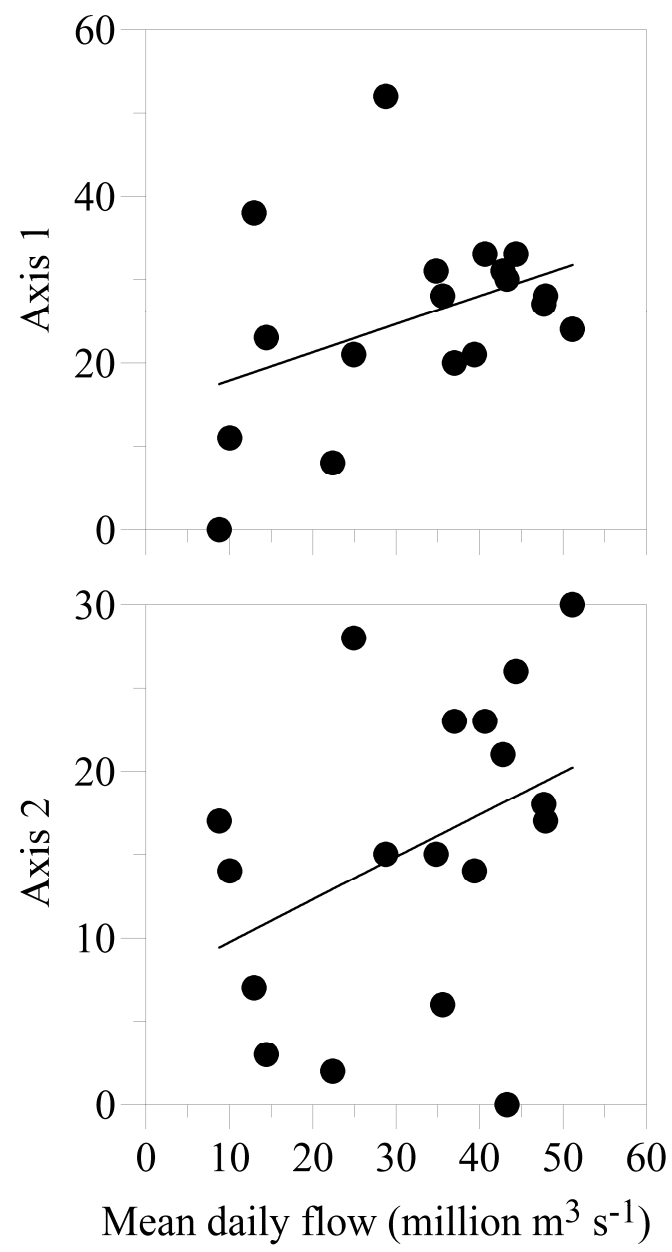

Figure 3. Relationship between maximum winter flood (mean daily gauged flow for the winter month with the highest flood waters) and the values derived from a detrended correspondence analysis for axis 1 and axis 2 in the ordination diagram, showing that winter flood contributes to both major axes and is important in explaining patterns of variability in avian community across 18 years. 


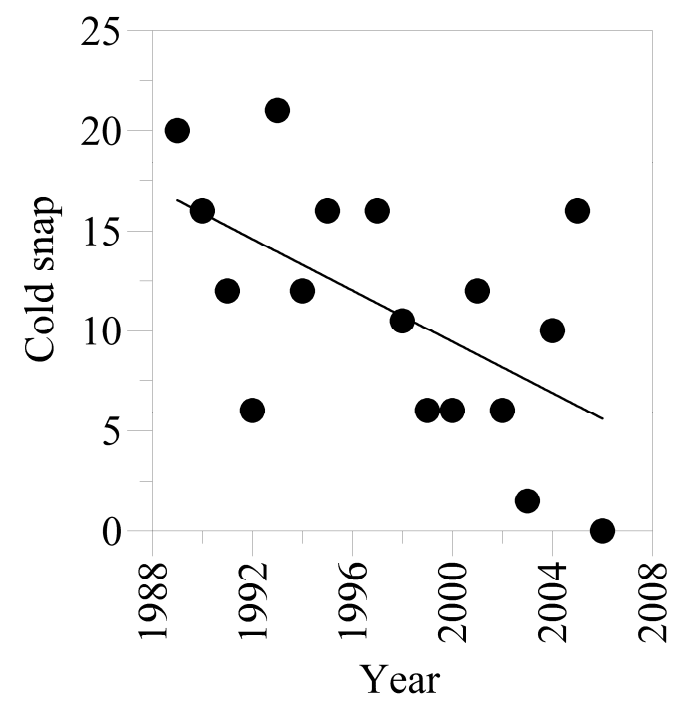

Figure 4. Relationship between the index for cold snap and year, showing the decline through time. 